\title{
Pemeriksaan Tunggal Kadar Osteopontin Serum dan CA 125 untuk Prediktor Keganasan Tumor Ovarium Tipe Epitel: Inferior dibandingkan dengan Pemeriksaan Gabungan
}

\author{
Aditiyono, ${ }^{1}$ Ali Budi Harsono, ${ }^{2}$ Gatot N.A.Winarno, ${ }^{2}$ Supriadi Gandamihardja, ${ }^{2}$ \\ Ardhanu Kusumanto, ${ }^{3}$ Herman Susanto ${ }^{2}$ \\ ${ }^{1}$ Fakultas Kedokteran Universitas Jendral Soedirman/RS Margono Soekarjo Purwokerto \\ ${ }^{2}$ Fakultas Kedokteran Universitas Padjadjaran/ RSUP dr.Hasan Sadikin Bandung \\ ${ }^{3}$ Fakultas Kedokteran Universitas Gadjah Mada/Rumah Sakit Sardjito Yogyakarta \\ Korespondensi: Aditiyono, Email: draditiyono@gmail.com
}

\begin{abstract}
Abstrak
Tujuan: Membandingkan penanda tumor osteopontin (OPN), cancer antigen 125 (CA125), kombinasi sebagai prediktor keganasan pada penderita tumor ovarium.

Metode: Penelitian cross sectional ini dilakukan pada pasien dengan keganasan pada kista ovarium jenis epitel. Analisis data dilakukan secara univariat dan bivariat.

Hasil: 47 pasien dengan hasil hitopatologi jinak dan 43 dengan hasil histopatologi ganas masuk dalam penelitian. Hasil nilai median CA125 kelompok ganas dibanding kelompok jinak $(142,2$ vs $61,030, p<0,05)$, cut off point CA125 99,9 U/mL, sensitivitas 76,7\% dan spesifisitas 61,7\%. Kombinasi CA125 dan OPN memiliki sensitivitas lebih rendah dibandingkan CA125. Kombinasi CA125 dan OPN akan meningkatkan spesifitas, nilai duga positif dan akurasi yang lebih baik. Tumor marker OPN tidak tepat digunakan untuk proses deteksi dini, tetapi lebih tepat untuk penegakan diagnosis lebih baik dibandingkan dengan gold standard CA125.

Kesimpulan: Kombinasi OPN dan CA125 memiliki nilai tingkat akurasi paling tinggi apabila dibandingkan pemeriksaan tunggal CA125, OPN.
\end{abstract}

Kata Kunci: tumor ovarium tipe epitel, OPN, CA 125, prediktor keganasan

\section{Single Check of Serum Ostepontin and CA 125 Levels as A Predictor of Malignancy in Epitheliaal Ovarium Tumor is Inferior to Combined Examination}

\begin{abstract}
Objective: To compare the sensitivity, specificity, expected value positive, expected value negative and accuracy among osteopontin (OPN), cancer antigen 125 (CA125), and combination as predictor of malignancy in ovarian tumor patients.

Method: A cross sectional study was done to compare parameters OPN and CA125 in determining malignancy of ovarian cysts. Data analysis was performed by univariate and bivariate analysis. A total of 47 subjects were included with benign histopathological result and 43 subjects with malignant histopathological result. The median value of CA125 in malignant group was compared to that of benign group (142.2 vs. 61.030, $p$ value $<0.05)$, the cut-off point of CA125 was $99.9 \mathrm{U} / \mathrm{mL}$ with sensitivity of $76.7 \%$ and specificity of $61.7 \%$.

Discussion: Combination of CA125 dan OPN has lower sensitivity compared to single tumor marker CA125. This combination will increase specificity, positive predictive value and accuracy. The OPN is inappropriate when used for early detection instead is suggested for diagnostic value risk predictor for malignancy in ovarian tumor compared to gold standard CA125.

Conclusions: Combination OPN dan CA125 has higher accuracy compared to single CA125, and OPN. OPN was useful biomarker for predicting ovarian malignancy.
\end{abstract}

Keywords: Epithelial ovarian tumor, OPN, CA 125, predictor for ovarian malignancy 


\section{Pendahuluan}

Keganasan ovarium memiliki angka morbiditas dan mortalitas yang tinggi karena umumnya ditemukan pada stadium lanjut. Hal ini terjadi antara lain oleh sulitnya untuk melakukan deteksi dini dengan tidak munculnya gejala klinik yang dapat dikenali dan rendahnya sensitivitas metode deteksi dini. Menurut data World Health Organization (WHO) 2012 kejadian kanker ovarium pada wanita berada di urutan ke tujuh. ${ }^{1}$

Perkembangan lain untuk meningkatkan akurasi diagnostik tumor ganas ovarium adalah penanda tumor. Salah satu penanda tumor yang dapat dipakai sebagai penanda tumor ovarium adalah Cancer antigen 125 (CA 125) yang merupakan glikoprotein dengan berat molekul tinggi dan terletak di permukaan sel, ditemukan pada $80 \%$ keganasan ovarium tipe epitel serosum. ${ }^{2}$ Penapisan dengan pemeriksaan CA 125 kurang memuaskan karena menunjukkan hasil nilai nilai sensitivitas (84,4\%) dan spesifisitas (66,3\%) yang rendah. ${ }^{3,4}$ Protein CA125 yang mengikat E-cadherin dan kompleks $\beta$-catenin, menghasilkan peningkatan motilitas, migrasi, dan invasi sel yang mengekspresikan CA125. Seperti dengan beberapa biomarker kanker ovarium lainnya, CA125 mengekspresikan sel sinyal yang meningkatkan aktivasi reseptor faktor pertumbuhan epidermal (EGFR), yang menghasilkan peningkatan efektor Akt dan ERK1 / 2 dan peningkatkan eksperesi MMP-2 dan MMP-9. Terdapat peningkatan kadar CA 125 pada $1-2 \%$ individu normal yang sehat, juga pada $5 \%$ pada mereka dengan tumor jinak, dan 28\% meningkat pada penderita tumor ganas non ginekologi sehingga tidak direkomendasikan untuk deteksi dini pasien tanpa gejala. False positive pada pemeriksaan CA 125 dapat terjadi pada berbagai kondisi terutama kondisi-kondisi yang berkaitan dengan inflamasi peritoneum..$^{2,5-7}$

Osteopontin (OPN) merupakan protein non-kolagen, menyerupai kemokin, matriks seluler fosfoglikoprotein yang memfasilitasi interaksi sel-matriks dan mempromosikan perkembangan tumor. OPN adalah anggota dari small integrin-binding ligand $N$-linked glycoproteins (SIBLINGs), golongan dari lima integrin yang berikatan dengan glikofosfoprotein. Terdapat data dan bukti kuat bahwa OPN mempengaruhi beberapa langkah pertumbuhan tumor dan metastasis. OPN diekspresikan dalam berbagai jaringan dan cairan tubuh, dan diasosiasikan dengan beberapa patologi termasuk cedera jaringan, infeksi, penyakit auto imun dan kanker. ${ }^{8}$ OPN dikenal bekerja melalui beberapa integrin dan CD44 dan bersinergi melalui EGFR dan reseptor HGF, Met. OPN diekspresikan oleh beberapa jaringan dalam tubuh manusia, juga diekspresikan pada peningkatan sel tumor dari beberapa jenis kanker. OPN merupakan protein yang disekresikan, sehingga dapat dimanfaatkan untuk fungsi dan potensi diagnostik atau prognostik di beberapa kanker. ${ }^{8,9}$

Protein OPN berkaitan dengan keberadaan dan pertumbuhan neoplasma ovarium. Oleh karena itu, OPN bisa dianggap sebagai penanda diagnostik baru untuk memprediksi, mendeteksi, dan mengevaluasi neoplasma ovarium. ${ }^{4}$ Hal ini menunjukkan bahwa OPN bisa menjadi biomarker menjanjikan untuk prediksi neoplasma ovarium. ${ }^{4,10}$

Plasma OPN lebih tinggi konsentrasinya pada pasien neoplasma ovarium bila dibandingkan dengan wanita yang memiliki penyakit jinak ovarium atau individu yang sehat. Selain itu, penelitian sebelumnya telah menunjukkan bahwa peningkatan plasma tingkat OPN dapat meningkatkan proliferasi, migrasi, dan invasi neoplasma ovarium sel dengan mengaktifkan jalur sinyal dari phosphatidylinositol 3-kinase dan hipoxiainducible factor-1 $\alpha$, yang berkontribusi pada neoplasma ovarium. Peningkatan OPN serum dalam jaringan neoplasma ovarium 
berhubungan positif dengan metastasis pada kelenjar getah bening, stadium klinis dan grade histologis, konsentrasi OPN yang lebih tinggi berkorelasi dengan prognosis buruk, menunjukkan peningkatan mortalitas. Oleh karena itu, bahwa OPN bisa dianggap sebagai penanda diagnostik baru untuk memprediksi, mendeteksi, dan mengevaluasi neoplasma ovarium. Penanda tumor OPN yang diperiksa secara tersendiri sebagai prediksi keganasan ovarium atau digabungkan dengan CA 125 akan meningkatkan akurasi diagnostik prabedah tumor ovarium. ${ }^{5,8,9}$

Penelitian ini bertujuan mengukur dan membandingkan sensitivitas, spesifisitas, nilai duga positif, nilai duga negatif dan akurasi antara penanda tumor OPN, CA 125, kombinasi OPN dan CA 125 sebagai prediktor keganasan pada penderita tumor ovarium.

\section{Metode}

Subjek penelitian adalah pasien dengan kista ovarium yang akan dilakukan operasi di RSUP Dr. Hasan Sadikin Bandung pada periode April-September 2017. Sampel yang memenuhi kriteria inklusi dan tidak termasuk kriteria eksklusi, serta bersedia mengikuti penelitian dengan menandatangani lembar informed consent. Kriteria Inklusi wanita dengan tumor ovarium dan direncanakan dilakukan operasi, tidak menderita penyakit sumsum tulang maupun penyakit gangguan darah lainnya dan tidak menderita penyakit inflamasi akut. Kriteria eksklusi histopatologi untuk tumor ganas ovarium bukan tipe epitel, memiliki tumor atau kanker lain selain ovarium dan riwayat kemoterapi sebelum operasi.

Penelitian cross sectional atau potong lintang dengan analisis uji diagnostik untuk mengetahui dari parameter (kadar OPN dan CA125) yang dilakukan penelitian, parameter manakah yang lebih sensitif dan spesifik dalam menentukan suatu keganasan pada kista ovarium dari semua subjek penelitian yang memenuhi kriteria penelitian. Besar sampel pada penelitian ini ditentukan dengan rumus besar sampel untuk uji diagnostik berupa nilai sensitivitas, dan spesifisitas bahan pemeriksaan, yaitu: berdasarkan nilai sensitivitas pemeriksaan yang diharapkan berdasarkan penelitian OPN sebelumnya sebesar $0,76^{11}$ dan CA 125 0,743 dengan memilih taraf kepercayaan $95 \%$ dan presisi $10 \%$. Uji statistik untuk membandingkan data numerik dua kelompok dengan uji $\mathrm{t}$ tidak berpasangan apabila data berdistribusi normal, dengan alternatif uji Mann Whitney apabila data tidak berdistribusi normal. Sedangkan Analisis statistik untuk data kategorik diuji dengan uji Chi-kuadrat apabila syarat Chi-kuadrat terpenuhi. Adapun kriteria kemaknaan yang digunakan adalah nilai $p$ dengan ketentuan apabila $p \leq 0,05$ artinya signifikan. Untuk menggambarkan sensitivitas dan spesifisitas dari data numerik, maka akan disajikan dalam kurva Receiver Operating Characteristic (ROC). Berdasarkan kurva ROC maka diperoleh nilai area under curve (AUC). Data yang diperoleh dicatat dalam formulir khusus kemudian diolah melalui program statistical product and service solution (SPSS) versi 25.0 for windows ${ }^{12}$

\section{Hasil}

Pada tabel 1 karakteristik subjek penelitian berdasarkan usia, status menopause, BMI dan leukosit pada kelompok ganas dan jinak. Untuk usia pada kelompok ganas memiliki rata-rata sebesar 45,72 $\pm 13,266$ sedangkan untuk usia pada kelompok jinak memiliki rata-rata sebesar 39,51 $\pm 14,103$. Untuk pasien dengan status tidak menopause pada kelompok ganas sebanyak 22 atau sebesar $51,2 \%$ dan pasien yang menopause sebanyak 21 atau sebesar $17,2 \%$ sedangkan untuk pasien dengan status tidak menopause pada kelompok jinak sebanyak 32 atau sebesar 
$68,1 \%$ dan pasien yang menopause sebanyak 15 atau sebesar $31,9 \%$. Untuk BMI pada kelompok ganas memiliki median 20,4 sedangkan untuk BMI pada kelompok jinak memiliki median sebesar 23,6. Untuk leukosit pada kelompok ganas memiliki median sebesar 7800 sedangkan untuk leukosit pada kelompok jinak memiliki median sebesar 7300.

CA125 pada 142,2, sedangkan untuk CA125 pada kelompok jinak memiliki median 61,030 .

Hasil uji statistik pada kelompok penelitian di atas diperoleh informasi nilai $\mathrm{p}$ pada variabelCA125 lebih kecil dari 0.05 (nilai $\mathrm{p}<0,05)$. Dari hasil analisis perbandingan karakteristik kedua kelompok di atas, maka dapat disimpulkan kedua kelompok berbeda atau ada perbedaan karakteristik.
Untuk OPN pada kelompok ganas memiliki median sebesar 112,8 sedangkan untuk OPN $(\mathrm{ng} / \mathrm{mL})$ pada $(\mathrm{p}<0,05)$ kelompok jinak memiliki median 57,5.

Tabel 2 perbandingan karakteristik subjek penelitian berdasarkan hispatologi pada pasien tumor ovarium ganas dan jinak. Untuk histopatologi Serous carcinoma dan Endometrioid carcinoma 10 atau sebesar $23,3 \%$, mucinous carcinoma sebanyak 6 atau sebesar 14,0\%. Borderline serous sebanyak 5 atau sebesar 11,6\% dan Borderline mucinous sebanyak 8 atau sebesar $18,6 \%$ sedangkan untuk histopatologi dengan hasil serous kistadenoma sebanyak 13 atau sebesar 27,7\%, Mucinous kistadenoma sebanyak 20 atau sebesar $42,6 \%$, endometriosis sebanyak 14 atau sebesar $29,8 \%$.

\section{Tabel 1 Karakteristik Subjek Penelitian}

\begin{tabular}{lccc}
\hline \multirow{2}{*}{ Variabel } & \multicolumn{2}{c}{ Kelompok } & \\
\cline { 2 - 3 } & Ganas & Jinak & nilai p \\
& $\mathbf{N}=\mathbf{4 3}$ & $\mathbf{N}=\mathbf{4 7}$ & \\
\hline Usia (tahun) & & & $\mathbf{0 , 0 3 5 *}$ \\
Rerata (SB) & $45,72(13.3)$ & $39,51(14,1)$ & \\
Menopause & & & $\mathbf{0 , 1 0 2}$ \\
Tidak & $22(51,2 \%)$ & $32(68,1 \%)$ & \\
Ya & $21(17,2 \%)$ & $15(31,9 \%)$ & \\
BMI & & & $\mathbf{0 , 0 0 0 *}$ \\
Median & 20,4 & 23,6 & \\
Rentang & $14,60-34,00$ & $17,10-31,20$ & \\
Leukosit & & & $\mathbf{0 , 2 0 5}$ \\
Median & 7800 & 7300 & \\
Rentang & $4300-13800$ & $2560-16000$ & \\
CA125 & & & $\mathbf{0 , 0 0 0 *}$ \\
Median & 142,20 & 61,03 & \\
Rentang & $16,80-9934,00$ & $7,91-4747,0$ & \\
OPN (ng/mL) & & & $\mathbf{0 , 0 0 0 *}$ \\
Median & 112,8 & 57,5 & \\
Rentang & $34,40-700,00$ & $29,0-133,10$ & \\
\hline
\end{tabular}

Keterangan : Untuk data numerik nilai $\mathrm{p}$ diuji dengan uji t tidak berpasangan apabila data berdsitribusi normal dengan alternatif uji Mann Whitney pada data tidak berdistribusi normal. Untuk Data kategorik nilai p dihitung berdasarkan uji Chi-Square dengan alternatif uji Kolmogorov Smirnov dan Exact Fisher apabila syarat dari Chi-Square tidak terpenuhi. Nilai kemaknaan berdasarkan nilai $\mathrm{p}<0,05$.Tanda* menunjukkan nilai $\mathrm{p}<0,05$ artinya signifkan atau bermakna secara statistik. 
Tabel 2 Hispatologi pada Pasien Tumor Ovarium Ganas dan Jinak

\begin{tabular}{|c|c|c|c|}
\hline \multicolumn{4}{|c|}{ Kelompok } \\
\hline Ganas & & Jinak & \\
\hline $\mathrm{N}=43$ & & $\mathbf{N}=47$ & \\
\hline Hispatologi & & Histopatologi & \\
\hline Serous carcinoma & $10(23,3 \%)$ & Serous kistadenoma & $13(27,7 \%)$ \\
\hline Mucinous carcinoma & $6(14,0 \%)$ & Mucinous kistadenoma & $20(42,6 \%)$ \\
\hline $\begin{array}{l}\text { Endometrioid } \\
\text { carcinoma }\end{array}$ & $10(23,3 \%)$ & Endometriosis & $14(29,8 \%)$ \\
\hline Clear Cell carcinoma & $3(7,0 \%)$ & & \\
\hline $\begin{array}{l}\text { Seromuscinous } \\
\text { carcinoma }\end{array}$ & $1(2,3 \%)$ & & \\
\hline $\begin{array}{l}\text { Borderline serous } \\
\text { tumor }\end{array}$ & $5(11,6 \%)$ & & \\
\hline $\begin{array}{l}\text { Borderline mucinous } \\
\text { tumor }\end{array}$ & $8(18,6 \%)$ & & \\
\hline
\end{tabular}

Perbandingan kategori CA125 pada kelompok ganas dan jinak. Untuk kategori CA125 $<35 \mathrm{U} / \mathrm{mL}$ pada kelompok ganas sebanyak 2 atau sebesar $4,7 \%$ dan $\geq 35 \mathrm{U} / \mathrm{mL}$ sebanyak 41 atau sebesar 95,3\% sedangkan untuk kategori CA125 $<35 \mathrm{U} / \mathrm{mL}$ pada kelompok jinak sebanyak 10 atau sebesar $21,3 \%$ dan $\geq 35 \mathrm{U} / \mathrm{mL}$ sebanyak 37 atau sebesar $78,7 \%$.

Tabel 4 menjelaskan perbandingan antara cut off CA125 pada kelompok ganas dan jinak. Untuk cut off CA125 $\geq 99,9$ U/
$\mathrm{mL}$ pada kelompok ganas sebanyak 33 atau sebesar $76,7 \%$ dan cut off CA125 $<99,9$ $\mathrm{U} / \mathrm{mL}$ sebanyak 10 atau sebesar 23,3\% sedangkan untuk cut off CA125 $\geq 99,9 \mathrm{U} /$ $\mathrm{mL}$ pada kelompok jinak sebanyak 18 atau sebesar 38,3\% dan cut off CA125<99,9 $\mathrm{U} / \mathrm{mL}$ sebanyak 29 atau sebesar $61,7 \%$. Untuk analisis pada data kategorik yaitu cut off CA125 pada tabel diatas diuji dengan menggunakan uji statistika Chi-Square, nilai $\mathrm{p}$ pada variabel cut off $\mathrm{CA} 125(\mathrm{P}<0,05)$.

\section{Tabel 3 Perbandingan Proporsi dan Hubungan dntara Cut Off CA125 pada Kelompok} Ganas dan Jinak

\begin{tabular}{lccc}
\hline & \multicolumn{2}{c}{ Kelompok } & \multirow{2}{*}{ Nilai p } \\
\cline { 2 - 3 } Variabel & $\begin{array}{c}\text { Ganas } \\
\mathbf{N = 4 3}\end{array}$ & Jinak & $\mathbf{N = 4 7}$ \\
CA125 cut off & & & $\mathbf{0 , 0 0 0 *}$ \\
$\geq \mathbf{9 9 . 9} \mathbf{U} / \mathbf{m L}$ & $33(76,7 \%)$ & $18(38,3 \%)$ & \\
$<\mathbf{9 9 . 9} \mathbf{U} / \mathbf{m L}$ & $10(23,3 \%)$ & $29(61,7 \%)$ & \\
\hline
\end{tabular}

Keterangan: Data kategorik nilai p dihitung berdasarkan uji Chi-Square. Nilai kemaknaan berdasarkan nilai $\mathrm{p}<0,05$.Tanda* menunjukkan nilai $\mathrm{p}<0,05$ artinya signifkan atau bermakna secara statistik

Sensitivitas $=\mathrm{a} /(\mathrm{a}+\mathrm{c})=33 / 43 \times 100 \%=76,7 \%$

Spesifisitas $=d /(b+d)=29 / 47 \times 100 \%=61,7 \%$

Nilai duga positif $=\mathrm{a} /(\mathrm{a}+\mathrm{b})=33 / 51 \times 100 \%=64,7 \%$

Nilai Duga Negatif $=d /(c+d)=29 / 39 \times 100 \%=74,3 \%$

Akurasi $=(\mathrm{a}+\mathrm{d}) / \mathrm{N}=62 / 90 \mathrm{x} 100 \%=68,8 \%$ 
Berdasarkan perhitungan yang dilakukan, cut off point CA125 pada penelitian ini adalah 99,9 U/mL dengan nilai sensitivitas $76,7 \%$ dan nilai spesifisitas $61,7 \%$. Hal ini berarti bahwa $77,5 \%$ pasien dengan CA125 > 99,9 $\mathrm{U} / \mathrm{mL}$ diprediksi akan mengalami tumor ovarium ganas. Berdasarkan perhitungan di atas maka sensitifitas memiliki nilai hampir sama dengan spesifisitas sehingga dapat disimpulkan bahwa sensitivitas dan spesifitas menghasilkan nilai kecermatan positif yang berbeda dengan nilai kecermatan negatif.

Kurva ROC (receiver operating characteristic) menunjukkan bahwa CA125 mempunyai nilai diagnostik yang baik. Nilai AUC (area under the curve) yang diperoleh dari metode ROC adalah sebesar 77,5\% dengan nilai $\mathrm{p}$ sebesar 0,000 (gambar 1A). AUC 77,5\% artinya CA125 dapat digunakan untuk memprediksi keganasan tumor ovarium secara tepat pada 72 pasien dari total 90 pasien.

Berdasarkan interval kepercayaan, nilai CA125 berada pada level 67,9\% sampai $87,1 \%$ dan bermakna secara statistik.

Kurva ROC menunjukkan bahwa OPN (ng/mL) mempunyai nilai diagnostik yang baik. Nilai AUC yang diperoleh dari metode

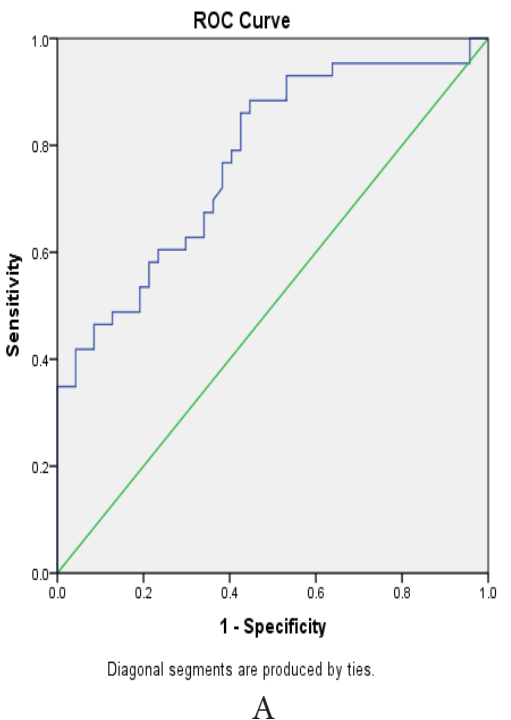

ROC adalah sebesar 78,8\% OPN dapat digunakan untuk memprediksi keganasan tumor ovarium secara tepat pada 71 pasien dari total 90 pasien.

Berdasarkan interval kepercayaan, nilai OPN (ng/mL) berada pada level 69,1\% sampai $88,6 \%$ dan bermakna secara statistik. Berdasarkan perhitungan yang dilakukan, cut off point OPN $(\mathrm{ng} / \mathrm{mL})$ pada penelitian ini adalah 70,6 dengan nilai sensitivitas $76,7 \%$ dan nilai spesifisitas $72,3 \%$. Hal ini berarti bahwa 78,8\% pasien dengan OPN $>70,6$ $\mathrm{ng} / \mathrm{mL}$ diprediksi akan mengalami tumor ovarium ganas. Berdasarkan perhitungan di atas maka sensitivitas memiliki nilai hampir sama dengan spesifisitas sehingga dapat disimpulkan bahwa sensitivitas dan spesifitas menghasilkan nilai kecermatan positif yang berbeda dengan nilai kecermatan negatif.

Tabel 5 menjelaskan perbandingan antara OPN (ng/mL) pada kelompok ganas dan jinak. Untuk OPN $\geq 70,6 \mathrm{ng} / \mathrm{mL}$ pada kelompok ganas sebanyak 33 atau sebesar $76,7 \%$ dan OPN <70,6 ng/mL sebanyak 10 atau sebesar $23.3 \%$ sedangkan untuk OPN $\geq 70,6 \mathrm{ng} / \mathrm{mL}$ pada kelompok jinak sebanyak 13 atau sebesar $27,7 \%$ dan OPN $<70,6 \mathrm{ng} / \mathrm{mL}$ sebanyak 34 atau sebesar $72,3 \%$.

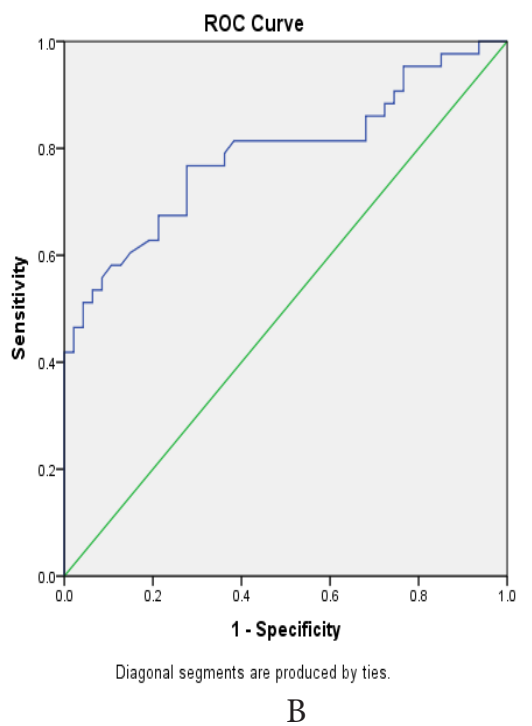

$\mathrm{B}$ 
Tabel 4 Perbandingan Proporsi dan Hubungan antara Kategori OPN (Ng/MI) pada Kelompok Ganas dan Jinak Berdasarkan Cut Off Point

\begin{tabular}{lccc}
\hline \multirow{2}{*}{ Variabel } & \multicolumn{2}{c}{ Kelompok } & \\
\cline { 2 - 3 } & $\begin{array}{c}\text { Ganas } \\
\mathbf{N}=\mathbf{4 3}\end{array}$ & $\begin{array}{c}\text { Jinak } \\
\mathbf{N}=\mathbf{4 7}\end{array}$ & \\
\hline OPN (ng/mL) & & & $\mathbf{0 , 0 0 0 *}$ \\
$\geq 70,6$ & 33 & 13 & \\
& $(76,7 \%)$ & $(27,7 \%)$ & \\
$<70,6$ & 10 & 34 & \\
\hline
\end{tabular}

Keterangan : Data kategorik nilai $\mathrm{p}$ dihitung berdasarkan uji Chi-Square. Nilai kemaknaan berdasarkan nilai $\mathrm{p}<0,05$ .Tanda* menunjukkan nilai $\mathrm{p}<0,05$ artinya signifkan atau bermakna secara statistik.

sensitivitas $=a /(a+c)=33 / 43 \times 100 \%=76,7 \%$

spesifisitas $=d /(b+d)=34 / 47 \times 100 \%=72,3 \%$

nilai duga positif $=a /(a+b)=33 / 46 \times 100 \%=71,7 \%$

nilai duga negatif $=\mathrm{d} /(\mathrm{c}+\mathrm{d})=34 / 44 \times 100 \%=77,2 \%$

akurasi $=(a+d) / n=67 / 90 \times 100 \%=74,4 \%$

Dari hasil analisis perbandingan karakteristik kedua kelompok di atas, maka dapat disimpulkan kedua kelompok berbeda atau ada perbedaan karakteristik. Maka secara statistik dapat disimpulkan terdapat hubungan antara nilai cut off point Kombinasi OPN+CA125 dengan keganasan tumor ovarium.

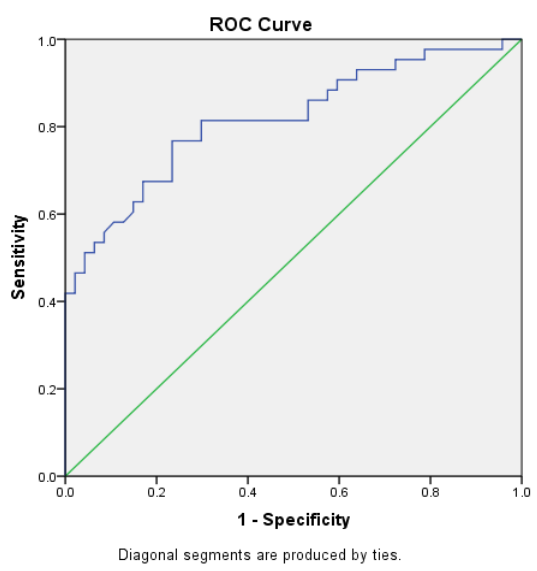

Gambar 2 Kombinasi OPN+CA125 serta Keganasan Tumor Ovarium
Gambar 2 Kurva ROC menunjukkan bahwa kombinasi OPN+CA125 mempunyai nilai diagnostik yang baik. Nilai AUC yang diperoleh dari metode ROC adalah sebesar $81,7 \%$ dengan nilai $\mathrm{p}$ sebesar 0,000 , artinya adalah signifikan. AUC $81,7 \%$ artinya kombinasi OPN+CA125 dapat digunakan untuk memprediksi keganasan tumor ovarium secara tepat pada 74 pasien dari total 90 pasien.

Berdasarkan interval kepercayaan, nilai kombinasi OPN + CA125 berada pada level $72,8 \%$ sampai $90,6 \%$ dan bermakna secara statistik.

Berdasarkanperhitunganyangdilakukan, cut off point kombinasi OPN+CA125 pada penelitian ini adalah 141,20 dengan nilai sensitivitas $76,7 \%$ dan nilai spesifisitas $76,5 \%$. Hal ini berarti bahwa $81,7 \%$ pasien dengan kombinasi OPN+CA125 lebih besar dari 141,2 diprediksi akan mengalami tumor ovarium ganas. Berdasarkan perhitungan di atas maka sensitivitas memiliki nilai hampir sama dengan spesifisitas sehingga dapat disimpulkan bahwa sensitivitas dan spesifitas menghasilkan nilai kecermatan positif yang berbeda dengan nilai kecermatan negatif.

Pada perbandingan antara cut off kombinasi OPN+CA125 pada kelompok ganas dan jinak. Untuk cut off kombinasi OPN+CA125 >141,20 pada kelompok ganas sebanyak 33 atau sebesar $76,7 \%$ dan cut off kombinasi OPN+CA125 <141,20 sebanyak 10 atau sebesar $23,3 \%$ sedangkan untuk cut off kombinasi OPN+CA125 $>141,20$ pada kelompok jinak sebanyak 11 atau sebesar $23,4 \%$ dan cut off kombinasi OPN+CA125 $<141,20$ sebanyak 36 atau sebesar 76,6\%.

Untuk analisis pada data kategorik yaitu cut off kombinasi OPN+CA125 pada tabel di atas diuji dengan menggunakan uji statistika Chi-Square yaitu cut off kombinasi OPN+CA125. Hasil uji statistik pada kelompok penelitian di atas diperoleh informasi nilai $\mathrm{p}$ pada variabel cut off kombinasi OPN+CA125 lebih kecil dari 0.05 
Tabel 5 Nilai Sensitivitas, Spesifitas, Nilai Duga Postif, Nilai Duga Negatif serta Akurasi dari Pemeriksaan Ca 125, Opn Dan Opn+Ca125

\begin{tabular}{lccccc}
\hline \multirow{2}{*}{ Variabel } & Sensitivitas & Spesifisitas & $\begin{array}{c}\text { Nilai duga } \\
\text { positif }\end{array}$ & $\begin{array}{c}\text { Nilai duga } \\
\text { negatif }\end{array}$ & Akurasi \\
\cline { 2 - 5 } & & 21,3 & 52,5 & 83,3 & 56,7 \\
CA 125 $\geq \mathbf{3 5} \mathbf{~ U / m L}$ & 95,3 & 61,7 & 64,7 & 74,3 & 68,8 \\
CA 125 $\geq \mathbf{9 9 , 9 ~ U / m l ~}$ & 76,7 & 72,3 & 71,7 & 77,2 & 74,4 \\
OPN $\geq \mathbf{7 0 , 6} \mathbf{~ n g / m L}$ & 76,7 & 76,5 & 75,0 & 78,2 & 76,6 \\
OPN + CA 125 & 76,7 & &
\end{tabular}

(nilai $\mathrm{p}<0.05$ ). Berdasarkan nilai sensitivitas di atas sebesar $76.7 \%$ menunjukkan nilai sensitivitas yang sedang secara statistik, sedangkan nilai spesifitas sebesar $76.5 \%$ menunjukan nilai spesifitas yang sedang secara statistik. Nilai duga positif (NDP) di atas yaitu sebesar $75.0 \%$ menunjukan NDP yang sedang secara statistik sedangkan nilai duga negatif (NDN) sedang yaitu sebesar $78,2 \%$ pada uji diagnostik ini. Untuk nilai akurasi sebesar $76,6 \%$ menunjukkan tingkat nilai akurasi yang sedang secara statistik.

Kekuatan dari masing-masing variabel yaitu menopause, OPN dan CA 125 dilihat dari nilai $\operatorname{Exp}(\mathrm{B})$. Kekuatan dari yang terbesar ke terkecil yaitu OPN (OR:7,229) dan CA 125 (OR: 8,783). Variabel menopause tidak bermakna.

Skor OPN $\geq 70,6 \mathrm{ng} / \mathrm{mL}=2$

OPN $<70,6 \mathrm{ng} / \mathrm{mL}=1$

CA $125 \geq 99,9 \mathrm{U} / \mathrm{mL}=2$

$\mathrm{CA} 125<99,9 \mathrm{U} / \mathrm{mL}=1$

menopause $=2$

premenopause $=1$

Nilai skor CA 125 dan OPN didapatkan dari cut off dari perhitungan pada penelitian ini. Probabilitas pasien ganas adalah $\mathrm{p}=1 /$ $\left(1+\mathrm{e}^{-\mathrm{y}}\right)$.

Rumus keganasan gabungan dari OPN, CA125 dan status menopause

$\Rightarrow \mathrm{y}=-5,694+(2,173) \quad(\mathrm{OPN})+1,978$

(CA 125)+-0,552 (Menopause)

$\Rightarrow \mathrm{e}=$ bilangan natural $=2,718$.

Menopause :

$$
\Rightarrow \mathrm{y}=-9,014+(2,480) \quad(\mathrm{OPN})+3,431
$$

(CA 125)
Premenopause :

$$
\Rightarrow \mathrm{y}=-4,596+(2,179)(\mathrm{OPN})+1,128
$$
(CA 125)

Hasil dari persamaan tersebut lalu dikonversikan sehingga didapatkan nilai $\mathrm{p}$, dengan menggunakan perintah eksponensial (EXP). Cut-off value estimasi tumor ganas jinak lebih 0,5 dan estimasi jinak kurang dari 0,5 . Jika nilai $\mathrm{p}=1 /\left(1+\mathrm{e}^{-\mathrm{y}}\right) \geq 0,5$, maka kemungkinan besar adalah ganas. Jika $p=1 /$ $\left(1+\mathrm{e}^{-\mathrm{y}}\right)<0,5$, maka tumor tersebut merupakan tumor jinak.

Hasil prediksi kombinasi OPN, CA125 dan status menopause, adalah sensitivitas $88,4 \%$ dan spesifisitas $44,7 \%$.

Sedangkan nilai duga positif $59,4 \%$ dan negatif $80,8 \%$, akurasi sebesar $65,6 \%$

Hasil OPN dan CA 125 pada menopause adalah sensitivitas $76,19 \%$ dan spesifisitas $86,66 \%$

Nilai duga positif $88,88 \%$ dan negatif $72,22 \% \%$, akurasi sebesar $80,55 \%$

Hasil prediksi OPN dan CA 125 pada premenopause, adalah sensitivitas $68,18 \%$ dans pesifisitas $81,25 \%$.

Sedangkan nilai duga positif $71,48 \%$ dan negatif $78,78 \%$, akurasi sebesar $75,92 \%$ 


\section{Pembahasan}

Pada Tabel 1 perbandingan karakteristik subjek penelitian berdasarkan usia, status menopause pada kelompok ganas dan jinak. Untuk usia pada kelompok ganas memiliki rata-rata sebesar 45,72 $\pm 13,266$ sedangkan untuk usia pada kelompok Jinak memiliki rata-rata sebesar 39,51 $\pm 14,103$. Untuk pasien dengan status tidak menopause pada kelompok ganas sebanyak 22 atau sebesar $51,2 \%$ dan pasien yang menopause sebanyak 21 atau sebesar $17,2 \%$ sedangkan Untuk pasien dengan status tidak menopause pada kelompok jinak sebanyak 32 atau sebesar $68,1 \%$ dan pasien yang menopause sebanyak 15 atau sebesar 31,9\%. SEER melaporkan bahwa antara tahun 2007-2011 proporsi karsinoma ovarium lebih banyak terjadi pada umur $>50$ (post-menopause) tahun sebesar $69,3 \%$ dengan frekuensi paling tinggi didapatkan antara umur 55 sampai dengan 64 tahun dengan median umur 63 tahun.

Cannistra melaporkan median umur pada negara berkembang 60 tahun dengan risiko 1 dari 70 wanita, risiko ini meningkat sejalan dengan makin lanjutnya umur sampai lebih dari 80 tahun dan kejadian keganasan ovarium tertinggi pada umur 60-65 tahun. Ketika keluhan klinis timbul maka pasien telah berada dalam stadium lanjut sehingga pada penelitian ini lebih dari dua pertiga kasus kasus keganasan ovarium didiagnosis ketika penyakit itu telah berkembang ke tahap III atau IV dan melibatkan rongga peritoneal atau organ lainnya. ${ }^{13-15}$

Kadar leukosit pada kedua kelompok tidak ada perbedaan bermakna antara kedua kelompok ganas dan jinak. Pada penelitian ini apabila terdapat tanda infeksi pasien diekslusikan. OPN diekspresikan dalam berbagai jaringan dan cairan tubuh, dan diasosiasikan dengan beberapa patologi termasuk cedera jaringan, infeksi, penyakit auto imun dan kanker. OPN diekspresikan dalam sel makrofag dalam beberapa patologi dan mengatur ekspresi sitokin, ekspresi yang diinduksi pembentukan nitrik oksida, fagositosis, dan migrasi ${ }^{8}$.

Untuk BMI pada kelompok ganas memiliki median 20,4, sedangkan untuk BMI pada kelompok jinak memiliki median 23,6, sesuai dengan penelitian Erondu yang melaporkan bahwa BMI berhubungan dengan gejala dan tanda dari keganasan ovarium, pada pasien dengan BMI lebih besar keluhan pada keganasan ovarium tidak tampak jelas, sehingga pasien cenderung datang dalam keadaan terlambat. Pasien dengan kanker agresif akan menunjukkan gejala lebih cepat dan mengalami penurunan fisik yang lebih cepat, sehingga menyebabkan mereka untuk segera melakukan perawatan medis. ${ }^{16}$

Pada saat ini merupakan satu-satunya penanda tumor yang telah terbukti untuk mendeteksi keganasan ovarium sebelum onset gejala klinis dan secara luas digunakan dalam praktek adalah CA 125. CA 125 dilaporkan memiliki satu sensitivitas tertinggi dan spesifisitas antara penanda tumor untuk keganasan ovarium. Nakae dkk menunjukkan bahwa di antara 32 pasien dengan keganasan ovarium, 34 pasien dengan ovarium jinak tumor, dan 31 wanita sehat, CA 125 memiliki sensitivitas $84,4 \%$ dan spesifitas $66,3 \%$ dalam memprediksi penyakit ini. Meskipun banyak manfaat yang menyertai penggunaan CA 125 , banyak tantangan yang membuatnya tidak efektif pada tahap deteksi dini. ${ }^{3,17}$

Pada penelitian ini didapatkan CA125 pada kelompok ganas memiliki median 142,2 U/mL sedangkan untuk CA125 pada kelompok jinak memiliki median 61,03. Hasil uji statistik pada kelompok penelitian di atas diperoleh informasi nilai $p$ pada variabel kategori CA125 lebih kecil dari 0,05 (nilai $\mathrm{p}<0,05$ ) yang berarti signifikan atau bermakna secara statistik dengan demikian dapat dijelaskan bahwa terdapat perbedaan persentase yang signifikan secara statistik antara variabel kategori CA125 pada kelompok ganas dan kelompok jinak. 
Pemeriksaan pada penelitian ini dengan cut off point CA $125 \geq 35 \mathrm{U} / \mathrm{mL}$ memiliki sensitivitas $95,3 \%$, spesifisitas $21,2 \%$, nilai duga positif $52,5 \%$ nilai duga negatif $83,3 \%$, serta akurasi $56,7 \%$, penelitian ini mungkin dapat dijelaskan pada penelitian oleh Skates dkk dimana batas (cut-off points) CA 125 yang dipakai saat ini yaitu $35 \mathrm{U} / \mathrm{mL}$ pada wanita yang menjalani deteksi dini tumor ganas ovarium perlu dipertimbangkan kembali dengan cara ikut melibatkan faktorfaktor antara lain kelompok pre-menopause, post-menopause dan sub-kelompok tertentu. Pada penelitian ini sensitivitas CA 125 dengan nilai cut off $\geq 99,9 \mathrm{U} / \mathrm{mL}$, adalah $76,7 \%$ dan spesifisitas 74,3\%. Skates dkk mendapatkan perbedaan yang bermakna kadar CA 125 pada kelompok wanita postmenopause dibandingkan dengan wanita pre-menopause sebagai kelompok kontrol, dimana pada kelompok post-menopause kadar CA 125 lebih tinggi dengan batas $52 \mathrm{U} /$ $\mathrm{mL}$ dibandingkan wanita premenopause yang memiliki kadar CA 125 dengan batas $35 \mathrm{U} /$ $\mathrm{mL}$.

Begitu juga bila dibandingkan dengan wanita pre-menopause yang menggunakan kontrasepsi oral dimana batas kadar CA125 adalah $40 \mathrm{U} / \mathrm{mL} .{ }^{18}$ Kadar CA125 yang tidak bermakna juga seperti yang didapatkan oleh Bast dkk dimana didapatkan hasil 99\% wanita sehat memiliki kadar serum CA 125 dibawah $35 \mathrm{U} / \mathrm{mL}$, sedangkan $82 \%$ wanita dengan tumor ganas ovarium tipe epitel memiliki kadar serum CA 125 di atas $35 \mathrm{U} / \mathrm{mL}$. Pada $90 \%$ kasus tumor ganas ovarium, kadar serum CA 125 berhubungan dengan volume tumor, bukan luas penyakit. Sebagai contoh kadar serum CA 125 pasien tumor ganas ovarium stadium IA dengan tumor berukuran $15 \mathrm{~cm}$ akan lebih tinggi bila dibandingkan dengan tumor ganas stadium IIB yang hanya berukuran $5 \mathrm{~cm}^{18,19}$. Pada penelitian ini CA $125 \geq 35 \mathrm{U} / \mathrm{mL}$ memiliki senstivitas tertinggi apabila dibandingkan dengan pemeriksaan OPN maupun OPN + CA 125 yaitu sebesar 95,3\%, yang menunjukkan bahwa pemeriksaan CA125 merupakan sebagai gold standard upaya deteksi dini. ${ }^{20}$

Pada penelitian Bao dkk mengungkapkan bahwa kadar OPN adalah prediktor yang independen dari prognosis kanker ovarium termasuk umur, ukuran tumor, dan jenis histologi. OPN mungkin berhubungan dengan metastasis peritoneum dan pada stadium lanjut, kadar OPN pada metastatasis bisa sebagai indikator prognostik pada kanker ovarium $^{21}$. Pada tabel 10 perbandingan antara OPN pada kelompok ganas dan jinak. Untuk OPN pada kelompok ganas memiliki median 112,8 ng/mL sedangkan untuk OPN pada kelompok jinak memiliki median 57,5 ng/mL. Berdasarkan kurva ROC (receiver operating characteristic) menunjukkan bahwa OPN mempunyai nilai diagnostik yang baik, nilai AUC (area under the curve) yang diperoleh dari metode ROC adalah sebesar 78,8\% dengan nilai $p$ sebesar 0,000 . Berdasarkan perhitungan yang dilakukan, $c u t$ off point OPN $(\mathrm{ng} / \mathrm{mL})$ pada penelitian ini adalah 70,6 ng/mL dengan nilai sensitivitas $76,7 \%$ dan nilai spesifisitas $72,3 \%$. Hal ini berarti bahwa $78,8 \%$ pasien dengan OPN (ng/ $\mathrm{mL}$ ) lebih besar dari 70,6 diprediksi sebagai tumor ovarium ganas. Pada penelitian Wang tahun 2013 serum OPN dengan cut off point $60 \mathrm{ng} / \mathrm{mL}$ dengan nilai sensitivitas $37,1 \%$ dan spesifitas 87,6\%. Pada penelitian Zhu dkk tahun 2016 menghasilkan bahwa sensitivitas dan spesifitas pemeriksaan OPN secara tunggal pada kanker ovarium adalah 0,766 dan 0,897. Pada penelitian Kim dkk menunjukkan bahwa OPN memiliki sensitivitas 80,4 dan $85,4 \%$ untuk mendeteksi kanker ovarium stadium awal (I / II) dan stadium lanjut (III ( IV), yang menunjukkan bahwa sensitivitas diagnostik OPN dapat lebih tinggi pada kanker ovarium dengan stadium yang lebih tinggi ${ }^{10,11,22}$.

OPN berguna dalam mendiagnosis kanker ovarium. Secara khusus, ketika OPN digunakan dalam kombinasi dengan 
CA125, peningkatan sensitivitas dalam mendiagnosis kanker ovarium lebih signifikan daripada ketika menggunakan penanda tunggal. Pemeriksaan CA 125 dan OPN sebagai prediktor keganasan ovarium memiliki nilai sensitivitas dan spesifitas ketika OPN dikombinasikan dengan CA 125 adalah 0,871 dan $0,88^{3}$. Pada penelitian ini kombinasi CA 125 dan OPN memiliki nilai sensitivitas $76,7 \%$, spesifisitas $76,5 \%$, nilai duga positif $75,0 \%$, nilai duga negatif $78,2 \%$ dan akurasi 76,6\%. Nilai tersebut lebih baik dibandingkan apabila hanya menggunakan OPN atau CA 125 secara tunggal. Kombinasi OPN dan CA125 memiliki nilai tingkat akurasi paling tinggi apabila dibandingkan CA 125, OPN. Penggunaan kombinasi CA 125 dan OPN memiliki sensitivitas lebih rendah dibandingkan penanda tumor tunggal CA 125. Kombinasi CA 125 dan OPN akan meningkatkan spesifitas, nilai duga positif dan akurasi yang lebih baik. Hal ini berarti bahwa OPN (baik sebagai penanda tumor tunggal maupun dalam kombinasi) tidak tepat digunakan untuk proses deteksi dini, tetapi lebih tepat untuk proses penegakan diagnosis (triase, penentuan risiko massa ovarium ganas dari jinak) yang lebih baik dibandingkan dengan gold standard saat ini yaitu CA125. Pada penggunaan rumus yang didapat dari tabel 8,9 dan 10 dengan cut-off value estimasi tumor ganas jinak adalah 0,5 dan estimasi jinak lebih besar dari 0,5. Jika nilai $\mathrm{p}=1 /\left(1+\mathrm{e}^{-\mathrm{y}}\right) \geq 0.5$, maka kemungkinan besar adalah ganas. Jika $\mathrm{p}=1 /\left(1+\mathrm{e}^{-\mathrm{y}}\right)<0,5$, maka tumor tersebut merupakan tumor jinak. Nilai sensitivitas rumus kombinasi OPN, CA125 dan status menopause $88,4 \%$, rumus premenopause $68,18 \%$ dan menopause $76,19 \%$. Nilai Spesifisitas rumus kombinasi OPN, CA125 dan status menopause $44,7 \%$, rumus premenopause $81,25 \%$ dan rumus menopause $86,66 \%$. Untuk akurasi rumus kombinasi OPN, CA125 dan status menopause adalah sebesar $65,6 \%$, rumus pada premenopause $75,92 \%$ dan akurasi rumus pada menopause $80,55 \%$. Simpulan, kombinasi OPN dan CA125 memiliki nilai tingkat akurasi paling tinggi apabila dibandingkan pemeriksaan tunggal CA125, OPN.

\section{Daftar Pustaka}

1. World Health Organization. GLOBOCAN 2012: estimated cancer incidence, mortality and pravalence wordwide in 2012. 2012 [updated 2012; Diunduh 1 Januari 2016]; Tersedia dari: http:// globocan.iarc.fr/Pages/fact_sheets_ population.aspx.

2. Bast RC, Jr. Biomarkers for ovarian cancer: new technologies and targets to address persistently unmet needs. Cancer biomarkers : section A of Disease markers. 2010;8(4-5):161-6.

3. Moss EL, Hollingworth J, Reynolds TM. The role of CA125 in clinical practice. J Clin Pathol. 2005;58(3):308-12.

4. Nakae M, Iwamoto I, Fujino T, Maehata Y, Togami S, Yoshinaga M, etal. Preoperative plasma osteopontin level as a biomarker complementary to carbohydrate antigen 125 in predicting ovarian cancer. The journal of obstetrics and gynaecology research. 2006;32(3):309-14.

5. Sarojini S, Tamir A, Lim H, Li S, Zhang S, Goy A, et al. Early detection biomarkers for ovarian cancer. J Oncol. 2012;2012:709049.

6. Jacobs IJ, Menon U. Progress and challenges in screening for early detection of ovarian cancer. Molecular \& cellular proteomics : MCP. 2004;3(4):355-66.

7. Cohen JG, White M, Cruz A, FariasEisner R. In 2014, can we do better than CA125 in the early detection of ovarian cancer? World Journal of Biological Chemistry. 2014;5(3):286-300.

8. Shevde LA, Samant RS. Role of osteopontin in the pathophysiology of cancer. Matrix Biol. 2014;37:131-41. 
9. Rittling SR, Chambers AF. Role of osteopontin in tumour progression. $\mathrm{Br} \mathrm{J}$ Cancer 2004;90(10):1877-81.

10. Wang YD, Chen H, Liu HQ, Hao M. Correlation between ovarian neoplasm and serum levels of osteopontin: a meta-analysis. Tumour Biol. 2014;35(12):11799-808.

11. 11. Lan Z, Fu D, Yu X, Xi M. Diagnostic values of osteopontin combined with CA125 forovarian cancer: a meta-analysis. Familial Cancer. 2016;15(2):221-30.

12. 12. Field A. Discovering statistics using IBM SPSS statistics.Edisi ke ke-4. London: Sage; 2013.

13. Howlader N, Noone A, Krapcho M, Garshell J, Neyman N, Altekruse S, et al. SEER Cancer Statistics Review, 19752011. National Cancer Institute Bethesda, MD. 2014(posted to the SEER web site, April 2014).

14. Cannistra SA. Cancer of the ovary. The New England journal of medicine. 2004;351(24):2519-29.

15. Siegel R, Ma J, Zou Z, Jemal A. Cancer statistics, 2014. CA: a cancer journal for clinicians. 2014;64(1):9-29.

16. Erondu CO, Alberg AJ, Bandera EV, Barnholtz-Sloan J, Bondy M, Cote ML, et al. The Association Between Body Mass Index and Presenting Symptoms in African American Women with Ovarian Cancer. Journal of Women's Health. 2016;25(6):571-8.
17. Rein BJ, Gupta S, Dada R, Safi J, Michener C, Agarwal A. Potential markers for detection and monitoring of ovarian cancer. J Oncol. 2011;2011:475983.

18. Skates SJ, Mai P, Horick NK, Piedmonte $\mathrm{M}$, Drescher $\mathrm{CW}$, Isaacs $\mathrm{C}$, et al. Large prospective study of ovarian cancer screening in high-risk women: CA125 cut-point defined by menopausal status. Cancer prevention research. 2011;4(9):1401-8.

19. Li J, Dowdy S, Tipton T, Podratz K, Lu WG, Xie X, et al. HE4 as a biomarker for ovarian and endometrial cancer management. Expert review of molecular diagnostics. 2009;9(6):555-66.

20. McIntosh MW, Drescher C, Karlan B, Scholler N, Urban N, Hellstrom KE, et al. Combining CA 125 and SMR serum markers for diagnosis and early detection of ovarian carcinoma. Gynecologic oncology. 2004;95(1):9-15.

21. Bao LH, Sakaguchi H, Fujimoto J, Tamaya T. Osteopontin in metastatic lesions as a prognostic marker in ovarian cancers. Journal of Biomedical Science. 2007;14(3):373-81.

22. $\mathrm{Hu} Z \mathrm{ZD}$, Wei TT, Yang M, Ma N, Tang QQ, Qin BD, et al. Diagnostic value of osteopontin in ovarian cancer: a metaanalysis and systematic review. PLoS One. 2015;10(5):e0126444. 